\title{
PENGGUNAAN STRATEGI STRUKTURAL DAN SEMANTIK DALAM TERJEMAHAN CERITA RAKYAT JEPANG "DONGURI DAN KUCING HUTAN" KARYA ANTONIUS PUDJO
}

\author{
Febi Ariani Saragih \\ Universitas Brawijaya \\ emiwk74@yahoo.co.jp
}

\begin{abstract}
In the world of translation, translators can use a variety of strategies. One is the structural and semantic strategy. This research discusses the method of translation by using the structural and semantic strategy of Japanese folk literature translated by Antonius Pudjo. There are three basic strategies related to structural issues, namely addition, subtraction, and transposition. As for the semantic strategy there are 9 strategies: levy, cultural equivalent, descriptive equivalent and component analysis, synonym, official translation, depreciation and expansion, addition, deletion, and modulation. This research is qualitative descriptive research. Research data is the translation of the story "Donguri and Kucing Hitam" in which using the structural and semantic strategy in the process of translation. Technique of collecting data is using documentation technique of read-record. While the technique of data analysis is done by analyzing one by one each translation from source language, then analyzed whether using structural or semantic strategy, and classified by type. From the 14 sentences taken as data, it is known that on the structural strategy found transposition strategy 6 sentences, semantic strategy found semantic strategy of adding and synonyming each 5 sentences, deletion 4 sentences, modulation 2 sentence, and levy 1 sentences. Of the 7 sentences used as data in uncovering the implicit meaning contained in the folklore, it is known that there is 1 referential meaning, 2 meanings of linguistic context, and 4 situational meanings. Not too much data is obtained, because besides the source language has made the sentences clearly, chances are also the translator wants the reader to enjoy the literary works as the original form. Antonius translation is good and the language is accepted by target language. In terms of grammatical, there are not many changes made by the translator, and can be categorized as loyal to resource language but idiomatic and communicative
\end{abstract}

Key Words: Structural Strategies, Semantic Strategies, Translating, Japanese Children Story

\section{PENDAHULUAN}

Penerjemahan merupakan salah satu cabang dari linguistik terapan sebagai bagian dari kegiatan dalam komunikasi antar manusia dengan berbagai bahasa yang berbeda. Suatu karya tulis bahasa asing tidak akan bisa kita nikmati apabila kita tidak menguasai bahasa asing tersebut, 
kecuali bila karya tulis tersebut dialihkan ke dalam bahasa yang kita kuasai. Penerjemahan juga semakin penting karena kebanyakan teks tentang informasi di segala bidang tertulis dalam bahasa asing. Dan hanya dengan terjemahan orang akan mengetahui dan memahami isi dari teks tersebut. Untuk itulah banyak bermunculan profesi penerjemah dewasa ini.

Dilihat dari fungsinya, suatu terjemahan bertujuan untuk menjembatani perbedaan ruang dan waktu (Suryawinata,2003:153). Yang pertama memindahkan makna dan pesan dalam BSu ke dalam BSa, dan yang kedua adalah memindahkan makna dan pesan dari suatu kurun waktu ke waktu lain yang berbeda. Karena kekhususan tersebut, maka diperlukan syarat bagi penerjemah karya sastra. Nida menyatakan bahwa penerjemah karya sastra perlu memiliki syarat-syarat antara lain memahami Bsu secara hampir sempurna. Dalam tingkat rekognisi kemampuannya diharapkan mendekati 100 persen; menguasai dan mampu memakai BSa dengan baik, benar dan efektif; megetahui dan memahami sastra, apresiasi sastra, serta teori terjemahan; mempunyai kepekaan terhadap karya sastra; memiliki keluwesan kognitif dan keluwesan sosiokultural; memiliki keuletan dan motivasi yang kuat.

Seperti yang telah dijelaskan diatas, bahwa dewasa ini banyak teks-teks asing yang telah diterjemahkan ke dalam bahasa Indonesia, baik dibidang Ilmu pengetahuan, teknologi, maupun budaya. Karya sastra merupakan salah satunya jenis teks yang banyak diterjemahkan. Untuk itulah penelitian membahas bagaimana penggunaan strategi struktural dan semantik dalam Cerita anak "Donguri dan Kucing Hutan", serta bagaimana makna implisit dalam cerita "Donguri dan Kucing Hutan". Antonius Pujo selaku penerjemah memiliki kemampuan mahir menerjemahkan karya sastra dan budaya Jepang. Dia bekerja sebagai dosen di Fakultas Sastra Univ. Airlangga,Surabaya. Buku karyanya adalah: Japanese Conversation, Kumpulan Cerita Rakyat Jepang, dan terjemahan "Bushido".

Menerjemahkan karya sastra merupakan usaha menjebatani dua kultur yang berbeda dengan dua bahasa yang berbeda. Namun kenyataannya sekarang ini banyak karya sastra yang diterjemahkan dari bahasa Asing ke dalam bahasa Indonesia. Salah satunya adalah novel (prosa fiksi). Masalah bagi seorang penerjemah dalam menerjemahkan prosa fiksi adalah pengaruh budaya sumber dan pesan moral yang ingin disampaikan oleh penulis aslinya. Dalam hal pengatur budaya BSa, kesulitan ini bisa berupa atura-aturan BSu, gaya bahasa, latar, dan tema. Sedangkan dalam hal pesan moral, penerjemah bisa menemukan kesulitan dalam hal idiolek, dan ciri-ciri khas penulis. 
Larson (1984:3) mengatakan bahwa terjemahan merupakan pentransferan makna dari bahasa pertama ke bahasa kedua dengan memperhatikan struktur semantiknya. Mengapa demikian, karena dalam proses penerjemahan sesorang penerjemah akan merubah unsur bahasa pertama ke dalam bahasa kedua yaitu unsur leksikal, gramatikal, dan semantik. Lebih lanjut Bell (1991:6) menyatakan bahwa terjemahan merupakan penggantian representasi teks yang sama ke dalam bahasa kedua khususnya yang berkaitan dengan kesamaan konteks, semantik, tata bahasa, leksis dan sebagainya pada tataran yang berbeda (kata untuk kata, frasa untuk frasa, dan kalimat untuk kalimat). Ini artinya pengalihan Bsu ke BSa adalah pengalihan unsur-unsur bahasa mulai tataran kata, frasa, sampai kalimat. Menurut Newmark, (1988:27) yang dikutip oleh Suryawinata (2003:118) menerjemahkan berarti memindahkan makna dari satu rangkaian atau satu unit linguistik dari satu bahasa ke bahasa yang lain. Dari tiga definisi tentang penerjemahan diatas, dapat disimpulkan bahwa makna merupakan salah satu bagian yang terpenting dalam proses penerjemahan, meskipun tidak bisa dipungkiri unsur-unsur yang lain juga mengambil peranan dalam proses penerjemahan.

Pegetahuan linguistk mutlak diperlukan dalam proses penerjemahan. Semantik sebagai salah satu bidang linguistik yang menekankan pengertian atas makna kata, sangat berperan dalam proses ini. Satu kata bisa mempunyai banyak makna tergantung pada konteks penggunaannya. Dalam penerjemahan mutlak digunakan pendekatan ilmiah terhadap analisis makna khususnya analisis satuan kata dan frasa.

Makna konteks linguistik adalah makna yang didapat dari makna referensial yang disusun secara semantik, lalu butir-butir informasinya dikemas atau disatukan dan diungkapkan dalam berbagai kombinasi. Misalnya, kata apel yang sudah dirujuk dalam teks dan kemudian dirujuk lagi, maka kenyataan bahwa apel itu adalah apel yang sama merupakan bagian makna konteks linguistik. Informasi tertentu dapat merupakan informasi lama (yang sudah disebutkan sebelumnya) atau informasi baru. Informasi bisa berupa topik wacana itu, atau sebutan tentang topik. Makna kontekstual linguistiklah yang menggabungkan informasi referensial ke dalam teks yang utuh (koheren). Makna linguistik kontekstual ditandai oleh deiktik, pengulangan, pengelompokan, dan banyak ciri lain dari struktur gramatikal sebuah teks. Misal dalam kalimat “Ani mengupas Apel” dan “Ani makan apel”, terdapat Ani dan Apel yang dirujuk dua kali. (makna referensial). Untuk membentuk struktur gramatikal yang benar, kita harus tahu apakah makna konteks linguistik itu mencakup hanya satu Ani dan satu Apel, atau apakah ada dua Ani dan dua 
apel. Jika hanya ada satu Ani, maka akan lahir struktur gramatikal, "Ani mengupas apel, dan kemudian memakannya". Tapi jika ada dua Ani yang diacu, maka struktur gramatikalnya harus ditunjukkan, misalnya, Ani mengupas apel, dan kemudian Ani yang lainnya memakannya. Tiap tiap bahasa mempunyai cara untuk menandai makna konteks linguistiknya. Misalnya bahasa yang menggunakan konstruksi pasif, makna tertentu dibiarkan implisit karena pelakunya tidak perlu disebutkan. Contoh, "Sekolah itu dibangun pada tahun 1902". Karena fokus pada "sekolah" maka orang yang mendirikan sekolah tersebut dibiarkan implisit.

Sedangkan makna situasional adalah amanat teks yang dihasilkan dalam suatu situasi komunikasi. Makna situasional ditentukan oleh tempat komunikasi itu berlangsung, waktu berlangsungnya, umur, jenis kelamin, status sosial, hubungan antara pembicara dan pendengar, praanggapan yang dibawa masing-masing pihak ke dalam komunikasi itu, latar belakang budaya pembicara dan orang yang disapanya, dll. Contoh, seorang istri yang berkata pada suaminya bahwa anaknya sakit, dia akan mengucapkan "Parto sakit pak". Tapi ketika dia mengucapkan kalimat tersebut pada dokter, maka ia akan mengucapkan "Anak saya parto sakit" atau "anak saya sakit".

Di dalam penerjemahan, masalah pokok yang sering dihadapi penerjemah adalah pemilihan metode penerjemahan yaitu menggunakan metode: penerjemahan harfiah ataukah penerjemahan bebas. Hoed dkk menjelaskan menjelaskan metode penerjemahan sebagai berikut: 1) Penerjemahan kata demi kata (word-for-word translation), 2) Penerjemahan Harfiah (literal translation), 3) Penerjemahan setia (faithful translation), 4) Penerjemahan semantik (Semantic translation), 5) Saduran (adaptation), 6) Penerjemahan bebas (free translation), 7) Penerjemahan Idiomatik (idiomatic translation), 8) Penerjemahan komunikatif (communicative translation).

Pengungkapan kembali pesan tidak hanya dilakukan dengan "mengorbankan "kesejajaran bentuk, tetapi juga kesejajaran makna. Tidak jarang penerjemah menghadapi kesulitan dalam memperoleh padanan dalam BSa karena memang bahasa tersebut tidak memiliki unsur yang dapat dipadankan. Perhatikan contoh dibawah ini:

$$
\begin{array}{ll}
\text { Katei kyoushi } & \text { : Guru privat } \\
\text { Oyasuminasai } & \text { : Selamat malam }
\end{array}
$$

Kata katei bermakna rumah tangga, kyoushi bermakna guru. Jadi jika disambung maka mempunyai arti guru rumah tangga. Karena tidak ada kata guru rumah tangga dalam bahasa Indonesia maka bisa disejajarkan dengan kata guru privat. Begitu juga kata “oyasumi nasai” yang merupakan salam ketika orang berpamitan akan tidur. Tapi dalam bahasa Indonesia, kita tidak 
mengatakan "selamat tidur", tetapi "selamat malam". Sedangkan "selamat malam" sendiri dalam bahasa Jepang digunakan ketika bertemu seseorang di malam hari. Apa yang dikemukakan di atas memperlihatkan bahwa demi kesepadanan, yakni pengungkapan pesan yang sama, penerjemah dapat menggunakan ungkapan yang kalau perlu maknanya tidak sejajar.

Strategi terjemahan adalah taktik penerjemah untuk menerjemahkan kata atau kelompok kata, atau mungkin kalimat penuh bila kalimat tersebut tidak bisa dipecah lagi menjadi unit yang lebih kecil untuk diterjemahkan. Ada beberapa strategi penerjemahan yang dibagi menjadi dua jenis utama. Pertama adalah strategi yang berkenaan dengan struktur kalimat. Strategi - strategi ini sebagian besar bersifat wajib dilakukan karena kalau tidak hasil terjemahannya akan tidak berterima secara struktural di dalam BSa, atau mungkin sekali tidak wajar. Jenis kedua adalah strategi yang langsung terkait dengan makna kata atau kalimat yang sedang diterjemahkan. (Suryawinata, 2003:67)

Ada tiga strategi dasar yang berkaitan dengan masalah struktur, yaitu penambahan, pengurangan, dan transposisi. Penambahan (addition) adalah dengan menambahkan kata-kata di dalam BSa karena struktur BSa menghendaki demikian. Penambahan jenis ini bukan masalah pilihan tapi suatu keharusan. Contoh: Raishuu iku tokoro wa Jakarta desu. (Tempat yang akan saya kunjungi minggu depan adalah Jakarta.); Pengurangan (substruction), yakni pengurangan elemen struktural di dalam BSa. Pengurangan ini merupakan keharusan juga. contoh: Watashi wa mikan ga suki desu. (Saya suka jeruk.); Transposisi (transposition). Strategi ini digunakan untuk menerjemahkan klausa atau kalimat. Strategi ini dipandang sebagai suatu keharusan atau sebagai pilihan. Keharusan apabila tanpa strategi ini makna BSu tidak tersampaikan. Menjadi pilihan jika apabila transposisi dilakukan karena alasan gaya bahasa saja. Artinya tanpa transposisi pun makna BSu sudah bisa diterima oleh pembaca BSa. Alasan kedua ini yang paling sering dilakukan. Jenisjenis transposisi misalnya pengubahan bentuk jamak ke tunggal, posisi kata sifat, sampai pengubahan struktur kalimat secara keseluruhan (Newmark,1988:85), pemisahan satu kalimat Bsu menjadi dua kalimat Bsa atau lebih, atau penggabungan dua kalimat Bsu atau lebih menjadi satu kalimat Bsa juga termasuk dalam strategi ini., contoh: akai kutsu o haitte iru onna no ko (Gadis kecil bersepatu merah.)

Selain itu, strategi semantik juga dilakukan dengan pertimbangan makna. Strategi ini ada yang digunakan pada tataran kata, frase maupun klausa atau kalimat. Strategi semantik terdiri dari: 
- Pungutan (Borrowing)

Pungutan adalah strategi penerjemahan yang membawa kata BSu ke dalam teks BSa. Penerjemah sekedar memungut kata BSu yang ada. Alasannya adalah untuk menunjukkan penghargaan terhadap kata-kata tersebut, atau belum ditemuinya padanan di dalam BSa. Pungutan bisa mencakup transliteralisasi dan naturalisasi. Transliteralisasi adalah strategi penerjemahan yang mempertahankan kata-kata BSu tersebut secara utuh, baik bunyi, ataupun tulisannya. Sedangkan naturalisasi adalah kelanjutan dari transliteralisasi. Dengan naturalisasi, kata-kata BSu tersebut ucapan dan penulisannya disesuaikan dengan aturan bahasa BSa. Naturalisasi sering disebut dengan adaptasi.

Contoh:

Haru no toki ni, shigoto ga awatte kara, hanami ni iku hito ga ooi.

Ketika musim semi, banyak orang yang pergi hanami setelah pulang kerja.

- Padanan Budaya

Dengan strategi ini penerjemah menggunakan kata khas dalam BSa utuk mengganti kata khas di dalam BSu. Yang harus diperhatikan adalah kata khas dalam BSu juga merupakan kata khas dalam BSa. Strategi ini kemungkinan tidak bisa menjaga ketepatan makna karena budaya suatu bahasa dengan budaya dari bahasa lain kemungkinan besar berbeda. Tetapi strategi ini bisa membuat kalimat dalam BSa menjadi mulus dan enak dibaca.

- Padanan deskriptif (descriptive equivalent) dan analisis komponensial (componential analisys).

Padanan ini berusaha mendeskripsikan makna atau fungsi dari kata BSu (Newmark, 1988:83-84). Strategi ini dilakukan karena kata BSu tersebut terkait dengan budaya khas BSu dan penggunaan padanan budaya dirasa tidak memberikan derajat ketepatan yang dikehendaki. Contoh, kata "samurai" tidak bisa diterjemahkan menjadi "kaum bangsawan" saja kalau teks yang bersangkutan menerangkan budaya Jepang. Tapi diterjemahkan menjadi aristokrat Jepang pada abad XI-XIX yang menjadi pegawai pemerintahan. Padanan ini biasanya ditempatkan dalam daftar kata-kata atau glossary. 
- Sedangkan analisis komponensial adalah menerjemahkan sebuah kata Bsu ke dalam BSa dengan cara merinci komponen-komponen makna kata Bsu. Ini dikarenakan tidak adanya padanan deskriptif yang digunakan untuk menerjemahkan kata yang terkait budaya.

- Sinonim

Penerjemah bisa menggunakan kata BSa yang kurang lebih sama untuk kata-kata Bsu yang bersifat umum kalau enggan menggunakan analisis komponensial. Strategi ini diambil karena analisis komponensial dirasa mengganggu alur kalimat BSa.

- Terjemahan Resmi

Strategi lain yang sering digunakan adalah terjemahan resmi yang telah dibakukan. Sehingga bagi penerjemah yang mengerjakan naskah dari bahasa Asing ke dalam bahasa Indonesia, perlu memiliki "Pedoman Pengindonesiaan Nama dan Kata Asing" yang dikeluarkan oleh pusat Pengembangan dan Pembinaan Bahasa Indonesia, Depdikbud RI.

- Penyusutan dan Perluasan

Penyusutan artinya penyusutan komponen kata BSu, sedangkan perluasan adalah unsur kata BSu diperluas di dalam BSa. Contoh: watashi wa sake ga suki. Diterjemahkan menjadi saya suka ikan sake. Diberi penambahan ikan, karena kalau tidak pembaca bisa saja mengartikan sebagai minuman.

- Penambahan

Berbeda dengan penambahan pada strategi struktural, penambahan ini dilakukan karena pertimbangan kejelasan makna. Penerjemah memasukkan informasi tambahan di dalam teks terjemahan karena ia berpendapat bahwa pembaca memang memerlukannya. Informasi tambahan ini bisa diletakkan di dalam teks, berupa catatan kaki atau di bagian akhir teks. (newmark, 1988:91-92). Penambahan bisa juga dilakukan karena pertimbangan stilistika atau kelancaran kalimat BSa.

1. Penghapusan

Penghapusan berarti penghapusan kata atau bagian teks BSu di dalam teks BSa. Dengan kata lain tidak diterjemahkannya kata atau bagian teks BSu di dalam teks BSa. Pertimbangannya adalah kata atau bagian teks BSu tersebut tidak begitu penting bagi keseluruhan teks BSa dan biasanya agak sulit untuk diterjemahkan.

2. Modulasi 
Modulasi adalah strategi untuk menerjemahkan frase, klausa, atau kalimat. Artinya, terjadi perubahan sudut pandang dalam aplikasi teknik ini (Newmark,1988:88). Strategi ini digunakan jika penerjemahan kata-kata dengan makna literal tidak menghasilkan terjemahan yang wajar atau luwes.

Contoh: watashi wa onaka ga itai

Perut saya sakit.

Contoh kalimat di atas adalah BSu mementingkan "perut" sebagai topik sedangkan BSa mementing subjek.

Dari beberapa contoh di atas dapat kita lihat bahwa sebenarnya strategi struktural dan semantik digunakan secara bersama-sama dan seringkali sukar dibedakan karena merupakan kombinasi dari beberapa jenis. Dan juga karena sudah demikian otomatisnya sehingga tidak disadari langkah-langkahnya. Untuk itu biasanya seorang penerjemah kadang tidak bisa menguraikan strategi yang mereka tempuh. Dari uraian di atas dapat disimpulkan bahwa dalam penerjemahan pesan lebih dipentingkan dari pada kesejajaran bentuk. Hasil penelitian ini dapat dijadikan referensi dalam matakuliah penerjemahan mengenai berbagai macam strategi penerjemahan, sedangkan dari segi praktis dapat menjadi masukan bagi para penerjemah pemula untuk belajar bagaimana cara menerjemahkan yang baik.

\section{METODE PENELITIAN}

Penelitian ini adalah penelitian deskriptif kualitatif, karena bertujuan untuk mencari fenomena yang terjadi dalam suatu karya terjemahan karya sastra yang dideskripsikan dengan kata-kata, bukan dengan angka. Penelitian ini akan melihat strategi apa saja yang digunakan dan makna implisit apa yang diungkapkan dalam penerjemahan oleh penerjemah dalam cerita rakyat “Donguri dan Kucing Hutan” karya Miyazawa Kenji. Data Penelitian adalah hasil terjemahan dari cerita "Donguri dan Kucing Hitam" yang didalamnya menggunakan strategi structural dan semantic dalam proses penerjemahannya. Teknik pengumpulan data penelitian ini menggunakan teknik dokumentasi baca-catat. Yaitu, peneliti membaca cerita asli dalam bahasa Jepang, kemudian membaca hasil terjemahan. Tiap-tiap kalimat ditulis versi asli dan disejajarkan dengan versi terjemahan. Sedangkan teknik analisis data dilakukan dengan cara menganalisis satu-persatu 
tiap hasil terjemahan dari Bahasa Sumber, kemudian dianalisis apakah menggunakan strategi structural atau semantic, serta diklasifikasikan berdasarkan jenisnya.

\section{PEMBAHASAN}

Dari 14 kalimat yang diambil sebagai data untuk melihat strategi yang digunakan penerjemah, diketahui bahwa pada strategi struktural ditemukan strategi transposisi 6 kalimat. Sedangkan pada strategi semantik ditemukan strategi semantik penambahan dan sinonim masingmasing 5 kalimat, penghapusan 4 kalimat, modulasi 2 kalimat dan pungutan 1 kalimat (untuk kalimat lain yang tidak dicantumkan sebagai data, terdapat 3 pungutan, dan selebihnya transposisi, penambahan, sinonim, dan penghapusan).

Dari 7 kalimat yang digunakan sebagai data dalam menyingkap makna implisit yang terkandung dalam cerita rakyat tersebut, diketahui ada 1 makna referensial, 2 makna konteks linguistik, dan 4 makna situasional. Tidak terlalu banyak data yang didapat, karena disamping BSu sudah membuat kalimat-kalimat dengan jelas, kemungkinan juga penerjemah ingin pembaca menikmati karya sastra tersebut sebagaimana bentuk aslinya.

\section{Penggunaan Strategi Struktural dan Semantik dalam Cerita anak "Donguri dan Kucing Hutan.}

Penggunaan Strategi Struktural dan semantik yang digunakan oleh pengarang tampak dalam kalimat-kalimat berikut ini:

a. おかしなはがきが、ある土曜日の夕方、一郎のうちにきました。 Sepucuk kartu pos yang aneh tiba di rumah Ichiro di hari Sabtu.

$\rightarrow$ Strategi semantik-penambahan.

Pada BSu tidak terdapat kata yang bermakan "sepucuk” (一通 atau 一枚) yang merupakan kata bantu bilangan untuk menghitung surat. Tetapi pengarang menambahkannya karena pertimbangan stilistika.

b. かねた一郎さま 九月十九

Tuan Kaneta Ichiro yang terhormat

$\rightarrow$ Strategi semantik-penambahan (stilistika)

Pada BSu tidak terdapat kata yang bermakna "terhormat"

c. こんなのです。

Demikian isi kartu pos tersebut

$\rightarrow$ Strategi struktural- transposisi (stilistika) 
Kalimat pada BSu kalau diterjemahkan secara harfiah hanya bermakna "Seperti ini". Makna "isi kartu pos" digantikan oleh partikel "no".

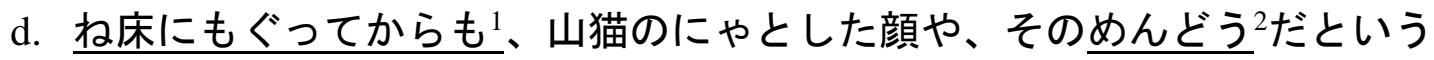
裁判のけしき3などを考えて、市そくまでねむりませんでした。

Meskipun ia berusaha tidur dengan cara menyusupkan kepala di bawah selimut sampai larut malam, ia tetap tidak bisa tidur karena wajah kucing yang sedang mengeong dan situasi persidangan yang rumit tersebut terus terbayang di dalam pikirannya

$\rightarrow$ Strategi semantik-penambahan (stilistika)

Kalimat BSu tidak terdapat kata yang bermakna "berusaha tidur dengan cara"

$\rightarrow$ Strategi semantik-sinonim

Kata pada BSu "mendo" bermakna merepotkan, tapi pengarang menggunakan kata "rumit".

$\rightarrow$ Strategi semantik - sinonim

Kata pada BSu "keshiki" bermakna pemandangan, tapi pengarang menggunakan kata "situasi"

$\rightarrow$ Strategi Semantik- Modulasi

Makna kalimat pada BSu "osoku made" memberi penekanan bahwa Ichiro tidak bisa tidur sampai larut malam, tapi pengarang kata "osoku made" diberikan untuk menekankan pada kalimat "menyusupkan kepala di bawah selimut.

e. けれども、一郎が眼をさましたときは、もうすっかり明るくなっていまし た。

Namun, ketika ia baru saja akan terlelap tidur, haripun sudah terlanjur terang.

$\rightarrow$ Strategi semantik-modulasi

Kalimat pada BSu "Ichiro ga me o samashita toki" sebenarnya bermakna "ketika ichiro terbangun", tapi oleh pengarang diterjemahkan "ketika ia baru saja terlelap tidur"

f. おもでに出てみると²、周りの山³ は、みんなたったいまできたばかりのよ うにうるうるもりあがって、真っ青なそらのしたにならんでいました。

Saat ia menuju ke depan rumah, gunung-gunung yang ada disekitarnya muncul seolah-olah baru saja terbentuk, berjajar di bawah langit yang biru.

$\rightarrow$ Struktur semantik-penambahan (stilistika)

Kata pada BSu "omote" bermakna "depan", tapi untuk lebih jelasnya oleh pengarang ditambahkan dengan kata "rumah"

$\rightarrow$ Strategi struktural - transposisi 
Kata pada BSu "dete miru" dari segi struktur tata bahasa bermakna "mencoba keluar", tapi oleh pengarang diterjemahkan menjadi "menuju"

Kata pada BSu "yama" yang berarti gunung (bentuk tunggal) diterjemahkan ke dalam bentuk jamak.

g. すきとおた風がざあっと吹くと、栗の木はばらばらと実をおとしました。 Begitu angin semilir bertiup, pohon kastanya ${ }^{1}$ menjatuhkan buah-buahnya sehingga berhamburan ke atas tanah.

$\rightarrow$ Strategi semantik - penambahan

Kata pada Bsu "Kuri no ki" diterjemahkan sebagai pohon kastanya dengan menggunakan catatatan kaki.

h. 一郎がまた少し行きますと、一本のぶなの木のしたに、たくさんの白いき のこが、どってこどってこどってこと、変な楽隊をやっていました。

Tapi, baru saja berjalan beberapa saat, ia menemukan sekelompok jamur putih yang sedang bermain musik aneh di bawah sebatang pohon buna ${ }^{2}$.

$\rightarrow$ Strategi semantik-sinonim

Kata "ikimasu" pada BSu bermakna "pergi" tapi oleh pengarang diterjemahkan "berjalan".

$\rightarrow$ Strategi semantik-pungutan

Kata pada BSu "buna" pada "ippon no buna no ki" tidak diterjemhakan karena belum ditemui padanan di dalam BSa.

$\rightarrow$ Strategi semantik-penghapusan

Kata pada BSu "dotte kodotte kodotte koto" tidak diterjemahkan oleh pengarang (dihilangkan) karena tidak begitu penting atau sulit untuk diterjemahkan.

i. 一郎は首をひねりました。

Ichiro memiringkan kepalanya keheranan

$\rightarrow$ Strategi semantik-sinonim

Kata "kubi o hinerimashita" pada BSu bermakna "memutar leher" tapi diterjemahkan menjadi "memiringkan kepala"

j. すると栗鼠は、杰の上から、額に手をかざして、一郎を見ながら答えまし た。

Tupai tersebut menempelkan tangannya di dahi sejenak, lalu memandang ke arah ichiro kemudian menjawab pertanyaan.

$\rightarrow$ Strategi semantik - penghapusan

Kata "ki no ue kara" pada BSu yang bermakna "dari atas pohon" tidak diterjemahkan oleh penerjemah. 
$\rightarrow$ Strategi struktural-transposisi

Kalimat "ichiro o minagara kotaemashita" pada BSu bermakna "sambil melihat/memandang ichiro menjawab pertanyaan" diterjemahkan menjadi "memandang ke arah ichiro, kemudian menjawab pertanyaan".

k. 一郎が顔を真っ赤にして、汗をぽとぽととおとしながら、その坂をのぼり ますと、にわかにぱっと明るくなって、眼がちくっとしました。

Jalannya yang sangat menanjak, membuat Ichiro harus mendaki dengan wajah memerah dan bercucuran keringat. Tiba-tiba pemandangan di depannya menjadi terang benderang dan menyilaukan mata.

$\rightarrow$ Struktural - Transposisi

1 kalimat pada BSu dipecah menjadi 2 kalimat. Penggunaan kata yang berjenis onomatope (gitaigo) "poto poto", "patt", dan "chikutt" yang berfungsi sebagai kata keterangan berubah menjadi kata kerja karena dalam bahasa Indonesia tidak ada padanan onomatopenya.

1. いい加減になかななおりをしたらどうだ。

Bagaimana kalau kalian berdamai saja?

Bagaimana kalau kalian rujuk saja?

$\rightarrow$ Strategi Semantik - penghapusan

Kata "ii kagen" pada BSu tidak diterjemahkan

$\rightarrow$ Strategi semantik - sinonim

Kata "naka naori" pada BSu yang bermakna "berdamai", diterjemahkan menjadi "rujuk"

m. どんぐりは、しいんとしてしまいました。それはそれはしいんとして、堅 まってしまいました。

Para donguri itu menjadi hening, hening sekali.

$\rightarrow$ Strategi struktural - transposisi

2 kalimat pada BSu diterjemahkan menjadi 1 kalimat.

n. すると、男はまた喜んで、まるで、顔じゅうロのようにして、にたにたに たにた笑って叫びました。

Laki-laki itu merasa senang lagi, ia tertawa dengan mulut terbuka lebar. Ia kemudian berteriak.

$\rightarrow$ Strategi struktural - transposisi

2 kalimat pada BSu diterjemahkan menjadi 1 kalimat

$\rightarrow$ Strategi semantik - penghapusan

Kata "nita-nita-nita-nita" dalam BSa tidak diterjemahkan 


\section{Makna Implisit dalam "Donguri dan Kucing Hutan"}

Kalimat yang mengandung makna implisit yang diterjemahkan oleh penerjemah adalah sebagai berikut:

a. おかしなはがきが、ある土曜日のタ方、一郎のうちにきました。

Sepucuk kartu pos yang aneh tiba di rumah Ichiro di hari Sabtu.

$\rightarrow$ Makna referensial

Meskipun tidak ada kata yang bermakna "sepucuk" pada BSu, tetapi dari kata hagaki (kartu pos) maka penggunaan kata bantu bilangan "sepucuk" bisa digunakan

b. かねた一郎さま 九月十九

Tuan Kaneta Ichiro yang terhormat

$\rightarrow$ Makna situasional

Tidak ada kata "yang terhormat" pada BSu, tapi dengan bantuan kata "Tuan", dan dalam situasi menulis disebuah kartu pos (=surat), maka penambahan kata "yang terhormat" menjadi tepat.

c. こんなのです。

Demikian isi kartu pos tersebut

$\rightarrow$ Makna konteks linguistik

Penggunaan kalimat di atas yang bermakna "seperti ini" adalah menyingkat informasi lama/sebelumnya. Sehingga penerjemah harus menjelaskan secara eksplisit maksud dari kalimat pendek tersebut.

d. おもでに出てみると、周りの山は、みんなたったいまできたばかりのよう にうるうるもりあがって、真っ青なそらのしたにならんでいました。 Saat ia menuju ke depan rumah, gunung-gunung yang ada disekitarnya muncul seolaholah baru saja terbentuk, berjajar di bawah langit yang biru.

$\rightarrow$ Makna situasional

Kata "omote" bermakna depan. Digunakan penambahan rumah, karena kalimat sesudahnya menggambarkan pemandangan gunung, dan Ichiro pada kalimat sebelumnya dalam kondisi di dalam rumah. 
e. すきとおた風がざあっと吹くと、栗の木はばらばらと実をおとしました。 Begitu angin semilir bertiup, pohon kastanya ${ }^{1}$ menjatuhkan buah-buahnya sehingga berhamburan ke atas tanah.

$\rightarrow$ Makna Situasional

Kata "mi" dalam BSu berjenis tunggal tetapi diterjemahkan jamak "buah-buahnya".

Ini karena terdapat kata "bara-bara" yang menggambarkan keadaan/situasi yang berhamburan/berserakan, sehingga tidak mungkin kalau bendanya tunggal.

f. すると一本のくるみの木の梢を、栗鼠がぴょんととんでいました。一郎はす ぐ手まねぎしてそれをとめて。

Ia melihat seekor tupai yang sedang melompat-lompat di atas pucuk sebatang pohon kenari. Ichiro segera melambaikan tangannya untuk menghentikan tupai tersebut.

$\rightarrow$ Makna konteks linguistik.

Kalimat "sore o tomete" bermakan "menghentikannya". Ini adalah untuk menyingkat informasi sebelumnya yaitu kata "tupai"

g. 男は喜んで、息をはあはあして、耳のあたりまで真っ赤になり、着物の襟を ひろげて、風を体に・・・

Laki-laki itu tampak senang, ia menarik nafas lega, namun bagian di sekitar telinganya menjadi merah karena menahan malu. Ia lalu membuka kancing kerah bajunya

$\rightarrow$ Makna situasional

Tidak ada kalimat atau kata yang bermakan "karena malu" dalam BSu, namun karena ada kalimat "disekitar telinganya menjadi merah" maka bisa dikatakan dalam kondisi malu.

\section{KESIMPULAN}

Larson menyatakan bahwa kualitas terjemahan ditentukan oleh ketepatan, kejelasan, dan kewajaran. Ketepatan berkaitan dengan pesan yang terkandung dalam BSu dan pesan yang terdapat pada teks BSa. Kejelasan berkaitan dengan tata bahasa dan tingkat kemudahan dalam pesan yang terdapat di BSa. Kewajaran berkaitan dengan gaya bahasa BSa yang dirasakan pembaca bukan dari hasil terjemahan. Terjemahan Antonius ini bisa dikatakan bagus dan bahasanya berterima oleh BSa. Jika dilihat dari segi gramatikal, tidak banyak perubahan yang dibuat oleh penerjemah, dan bisa dikategorikan setia terhadap BSu namun idiomatik dan 
komunikatif (Penerjemahan jenis ini berusaha menyampaikan makna teks dalam bahasa sumber dengan bentuk bahasa sasaran yang wajar, baik konstruksi gramatikal maupun pemilihan unsur leksikal, sehingga terjemahan macam ini "tidak terasa lagi” sebagai hasil terjemahan tetapi terasa seperti ditulis asli di dalam bahasa sasaran). Kalaupun terdapat penghapusan di beberapa tempat, itupun tidak mengurangi pesan yang ingin disampaikan pengarang. Semua strategi yang digunakan pengarang pada dasarnya bertujuan agar hasil terjemahan berterima oleh $\mathrm{BSa}$, dan menjadi terjemahan yang luwes. Meskipun terdapat kesepadanan dan ketidaksejajaran bentuk dan makna, tapi tidak mengurangi pesan yang ingin disampaikan pada karya yang aslinya. Penambahanpenambahan yang digunakan oleh penerjemah selain karena unsur gaya/stilistika, pada dasarnya adalah untuk mengungkap makna implisit yang terkandung dalam karya tersebut.

\section{DAFTAR PUSTAKA}

Bell, T.R, 1991, Translation and Translating: Theory and Practice $1^{\text {st }}$ Ed. New York: Longman

Hoed, B.H, 1979, dasar-dasar teoritis penerjemahan, pusat pembinaan dan pengembngan bahasa Jakarta

Hoed, B.H, 1991, Improving the capabilities of translation and institutionalizing Their profession in Indonesia, makalah dalam conference of the interpreter translator eductator's association of Australia, Melbourne, tidak diterbitkan

Larson, Mildred, 1984, Penerjemahan Berdasarkan Makna, Arcan, Jakarta

Newmark, P. 1988, A Textbook of translation, preticehall, London

Niida, E, 1945, Lingustics and Ethonology in Translation Problems. Word I 194-208. Reprinted in Hymes, ed. 1964,90-100

Purnomo, AP,2010, Antologi Kesusastraan Anak Jepang, Eramedia, Jakarta

Suryawinata, Z, 2003, Translation, Kanisius, Yogyakarta 